\title{
Mathematical modelling of greenhouse gas emissions from membrane bioreactors: A comprehensive comparison of two mathematical models
}

\author{
Giorgio Mannina $^{\mathrm{a}, \mathrm{b}, *}$, Alida Cosenza ${ }^{\mathrm{a}}$, George Ekama ${ }^{\mathrm{c}}$

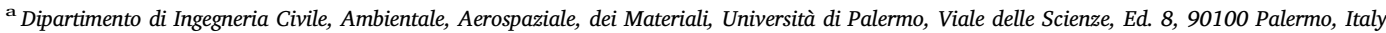 \\ ${ }^{\mathbf{b}}$ Department of Earth and Environmental Engineering, Columbia University, 500 West 120th Street, New York, NY 10027, USA \\ ${ }^{\mathrm{c}}$ Future Water Institute, University of Cape Town, Rondebosch, 7700 Cape, South Africa
}

\section{G R A P H I C A L A B S T R A C T}

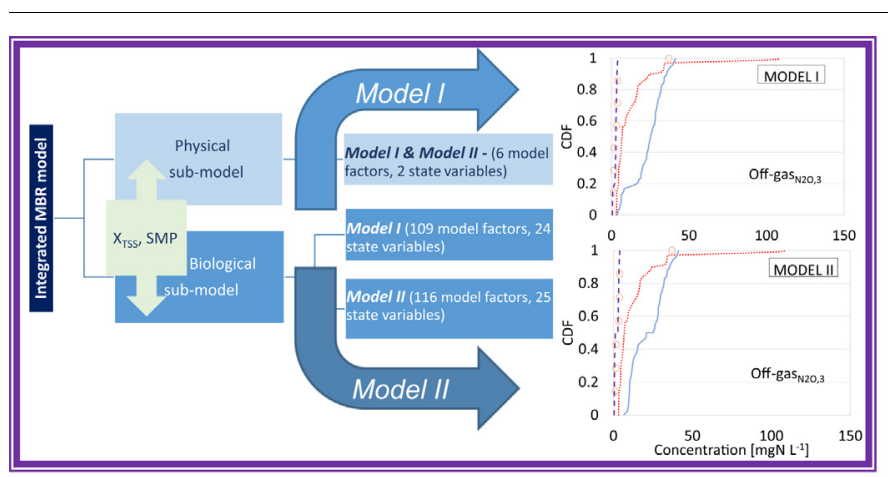

A R T I C L E I N F O

\section{Keywords:}

WWTP

$\mathrm{N}_{2} \mathrm{O}$ modelling

Nutrient removal

Greenhouse gases

\begin{abstract}
A B S T R A C T
This paper compares two mathematical models (Model I and Model II) to predict greenhouse gases emission from a University Cape Town (UCT) - membrane bioreactor (MBR) plant. Model I considers $\mathrm{N}_{2} \mathrm{O}$ production only during denitrification. Model II takes into account the ammonia-oxidizing bacteria (AOB) formation pathways for $\mathrm{N}_{2} \mathrm{O}$. Both models were calibrated adopting real data. Model comparison was performed in terms of (i) sensitivity analysis (ii) best fit and (iii) model prediction uncertainty. On average $6 \%$ of factors of Model I and $9 \%$ of Model II resulted to be important. In terms of best fit, Model II had a better capability of reproducing the measured data. The average efficiency related to the $\mathrm{N}_{2} \mathrm{O}$ model outputs was equal to 0.33 and 0.38 for Model I and Model II, respectively. On average, 73\% (Model I) and 86\% (Model II) of measured data lay inside the uncertainty bands.
\end{abstract}

\section{Introduction}

In recent years, attention on wastewater treatment plants (WWTPs) as sources of greenhouse gases (GHGs) (e.g., carbon dioxide, $\mathrm{CO}_{2}$, nitrous oxide, $\mathrm{N}_{2} \mathrm{O}$, and methane, $\mathrm{CH}_{4}$ ) has increased considerably
(Mannina et al., 2016a). Among the GHGs produced by WWTPs, $\mathrm{N}_{2} \mathrm{O}$ is the most environmentally hazardous due to its strong global warming potential (GWP) (298 higher that $\mathrm{CO}_{2}$ ) and its capacity to deplete the stratospheric ozone layer (IPCC et al., 2007).

An accurate quantification and mitigation of $\mathrm{N}_{2} \mathrm{O}$ emissions is

\footnotetext{
*Corresponding author at: Dipartimento di Ingegneria Civile, Ambientale, Aerospaziale, dei Materiali, Università di Palermo, Viale delle Scienze, Ed. 8, 90100 Palermo, Italy.

E-mail address: giorgio.mannina@unipa.it (G. Mannina).
} 


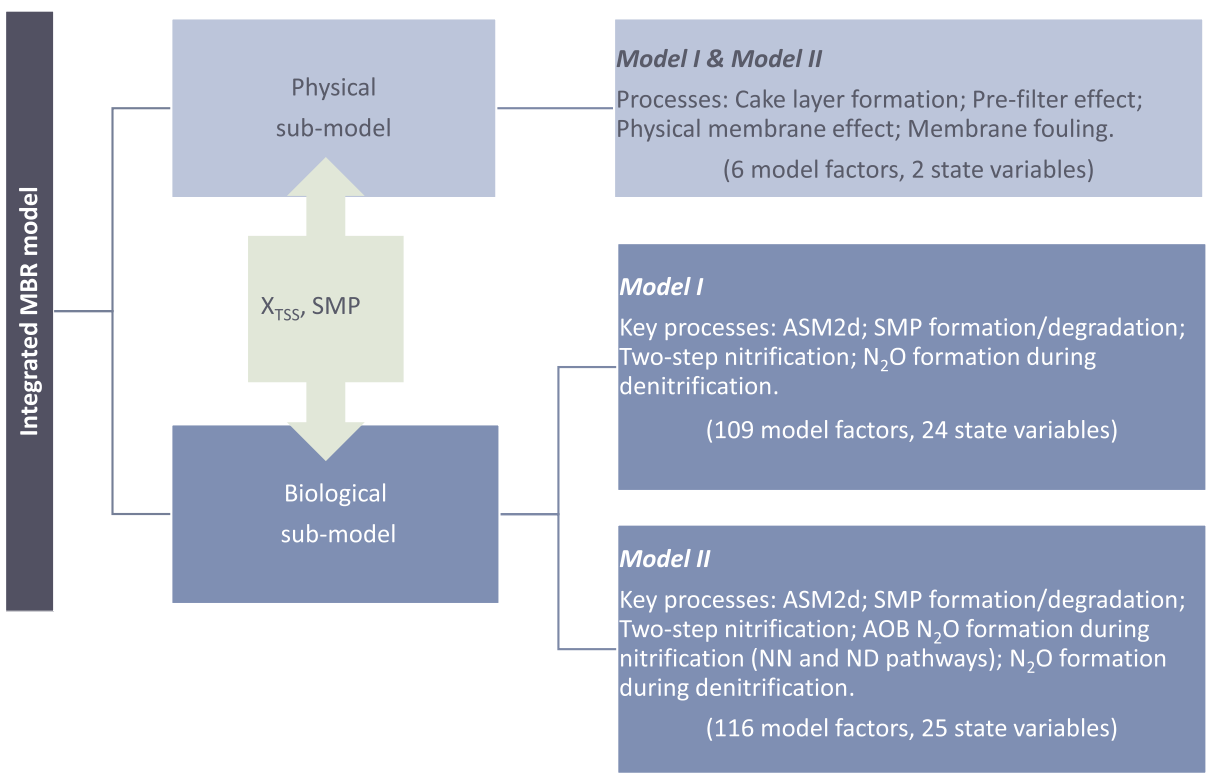

Fig. 1. Schematic overview of the structure of the integrated MBR Model I and II.

imperative for environmental protection. In this regard, the adoption of mathematical models allows the selection of appropriate design and/or operating choices aimed at reducing the total amount of GHG emissions from WWTPs.

Several efforts have been performed to establish the best tool to predict/quantify GHG emissions (Mannina et al., 2016a; Spérandio et al., 2016; Pocquet et al., 2016). However, the $\mathrm{N}_{2} \mathrm{O}$ estimation is still a major crucial aspect in GHG modelling since its formation mechanisms are still under review ( $\mathrm{Ni}$ et al., 2015). Current knowledge on $\mathrm{N}_{2} \mathrm{O}$ emissions suggests that it can be produced both during nitrification and denitrification processes. Autotrophic ammonia-oxidizing bacteria (AOB) can contribute to $\mathrm{N}_{2} \mathrm{O}$ production by means of two pathways: (i) the nitrifier denitrification (ND) pathway, where $\mathrm{N}_{2} \mathrm{O}$ represents the terminal product of nitrite reduction (Law et al., 2012) and (ii) the incomplete hydroxylamine $\left(\mathrm{NH}_{2} \mathrm{OH}\right)$ oxidation $(\mathrm{NN})$ pathway, where $\mathrm{N}_{2} \mathrm{O}$ is an intermediate product during the $\mathrm{NH}_{2} \mathrm{OH}$ oxidation (Pocquet et al., 2016). In this regard, literature suggests that mechanistic mathematical models that include both AOB contribution pathways should better reproduce the measured data (Peng et al., 2015). However, this has two critical aspects (i) the numerical handling of detailed models and (ii) the current knowledge has been acquired on non-advanced WWTPs.

The inclusion of detailed $\mathrm{N}_{2} \mathrm{O}$ processes makes the GHG mathematical models complex in terms of number of involved factors, state variables and processes. Therefore, the modeler has often to face the need to combine the huge numerical requirements of such models with fast and stable performance of the model response.

Sensitivity and uncertainty analyses can provide reliable support to the modeler for improving the model prediction despite the model complexity. Sensitivity analysis allows the selection of the key factors that mainly affect the model response, thus favoring the reduction of the computational time required for model calibration (Mannina et al., 2017). Further, uncertainty analysis indicates the confidence that can be placed in the model results (Sweetapple et al., 2013). Moreover, sensitivity and uncertainty analysis can allow better coding of the interrelationship between the processes, which is particularly relevant when both biological and physical processes are involved, such as in integrated membrane bioreactor (MBR) models. However, despite the usefulness of uncertainty analysis, only few such studies have been performed with complex Activated Sludge Models (ASM) including GHG formation and emission (Mannina et al., 2017; Sweetapple et al., 2013).
Regarding the second critical aspect, literature on the $\mathrm{N}_{2} \mathrm{O}$ modelling is focused on conventional activated sludge systems (CAS) and often rely on short-term data (Mannina et al., 2016a). Few studies have been performed to model integrated MBR systems where physical separation processes and biological processes affecting the membrane fouling (e.g., soluble microbial products - SMP - formation/degradation) both have to be included. Recently, an integrated ASM2d-SMP-GHG model (Model I) has been proposed (Mannina and Cosenza, 2015). The model is to predict the $\mathrm{N}_{2} \mathrm{O}$ and $\mathrm{CO}_{2}$ emission from a University Cape Town (UCT) - MBR plant. The model considers the $\mathrm{N}_{2} \mathrm{O}$ production only during the denitrification according to the approach of Hiatt and Grady Jr (2008). A new integrated MBR model including the two AOB formation pathways for $\mathrm{N}_{2} \mathrm{O}$ has been recently proposed by (ASM2d-SMP-GHG-2P-AOB) (Model II). The purpose of this study is to compare the response of the two models (i.e., Model I and Model II) for GHG emissions from a MBR system. The comparison has been performed in terms of three criteria (i) sensitivity analysis, (ii) best fit and (iii) model prediction uncertainty.

\section{Material and methods}

\subsection{Mathematical models description}

Model I and Model II are each divided in two sub-models (physical and biological) (Fig. 1). Table 1 summarizes the state variables of each model. The same physical sub-model was adopted in both models. It describes the key processes occurring during membrane physical separation, including membrane fouling (involving 6 model factors and 2 state variables).

The physical sub-model takes into account the following processes: (i) cake layer formation during the filtration and backwashing phases; (ii) partial organic matter (in terms of COD) removal due to the cakelayer; (iii) COD removal due to the physical retention effect of the membrane as barrier; (iv) membrane fouling (Fig. 1). The membrane fouling based on the $\mathrm{n}$ equal fractions (areal sections) approach of $\mathrm{Li}$ and Wang (2006) was adopted. A different intensity of the fluid turbulence $(G)$ on the membrane surface applied to each areal section depending on the distance from aerator.

For the membrane fouling description both reversible (which can be removed during the ordinary backwashing) and irreversible (which cannot be removed during the ordinary backwashing) were included. For a detailed description of physical sub-model the reader is referred to 
Table 1

State variables related to the biological sub-model of Model I and Model II.

\begin{tabular}{|c|c|c|}
\hline Symbol & Definition & Unit \\
\hline $\mathrm{S}_{\mathrm{O} 2}$ & Dissolved oxygen & $\mathrm{kg} \mathrm{COD} \mathrm{m}^{-3}$ \\
\hline $\mathrm{S}_{\mathrm{F}}$ & Fermentable organic matter & $\mathrm{kg} \operatorname{COD~m} \mathrm{m}^{-3}$ \\
\hline $\mathrm{S}_{\mathrm{A}}$ & Fermentation product (acetate) & $\mathrm{kg} \operatorname{COD~m^{-3}}$ \\
\hline $\mathrm{S}_{\mathrm{BAP}}$ & Soluble biomass associated products & $\mathrm{kg} \operatorname{COD~m^{-3}}$ \\
\hline $\mathrm{S}_{\mathrm{UAP}}$ & Soluble utilisation associated products & $\mathrm{kg} \mathrm{COD} \mathrm{m}^{-3}$ \\
\hline $\mathrm{S}_{\mathrm{NH} 4}$ & Ammonia & $\mathrm{kg} \mathrm{N} \mathrm{m}^{-3}$ \\
\hline $\mathrm{S}_{\mathrm{NH}_{2} \mathrm{OH}}^{*}$ & Hydroxilamine & $\mathrm{kg} \mathrm{N} \mathrm{m}^{-3}$ \\
\hline $\mathrm{S}_{\mathrm{NO} 3}$ & Nitrate & $\mathrm{kg} \mathrm{N} \mathrm{m}^{-3}$ \\
\hline $\mathrm{S}_{\mathrm{NO} 2}$ & Nitrite & $\mathrm{kg} \mathrm{N} \mathrm{m}^{-3}$ \\
\hline $\mathrm{S}_{\mathrm{NO}}$ & Nitric oxide & $\mathrm{kg} \mathrm{N} \mathrm{m}^{-3}$ \\
\hline $\mathrm{S}_{\mathrm{N} 2 \mathrm{O}}$ & Nitrous oxide & $\mathrm{kg} \mathrm{N} \mathrm{m}^{-3}$ \\
\hline $\mathrm{S}_{\mathrm{N} 2}$ & Dissolved nitrogen gas & $\mathrm{kg} \mathrm{N} \mathrm{m}^{-3}$ \\
\hline $\mathrm{S}_{\mathrm{PO} 4}$ & Soluble inorganic phosphorus & $\mathrm{kg} \mathrm{P} \mathrm{m}^{-3}$ \\
\hline $\mathrm{S}_{\mathrm{I}}$ & Soluble undegradable organics & $\mathrm{kg} \mathrm{COD} \mathrm{m}^{-3}$ \\
\hline $\mathrm{S}_{\mathrm{ALK}}$ & Alkalinity $\left(\mathrm{HCO}_{3}\right)$ & $\mathrm{mol} \mathrm{HCO}_{3} \mathrm{~m}^{-3}$ \\
\hline $\mathrm{S}_{\mathrm{CO} 2}$ & Dissolved carbon dioxide & $\mathrm{kgC} \mathrm{m}^{-3}$ \\
\hline$X_{I}$ & Particulate undegradable organics from the influent & $\mathrm{kg} \operatorname{COD~m} \mathrm{m}^{-3}$ \\
\hline $\mathrm{X}_{\mathrm{S}}$ & Particulate diodegradable organics & $\mathrm{kg}$ COD m $\mathrm{m}^{-3}$ \\
\hline $\mathrm{X}_{\mathrm{H}}$ & Heterotrophic organisms & $\mathrm{kg} \operatorname{COD~m}{ }^{-3}$ \\
\hline $\mathrm{X}_{\mathrm{PAO}}$ & Phosphorus Accumulating Organisms & $\mathrm{kg} \operatorname{COD~m^{-3}}$ \\
\hline $\mathrm{X}_{\mathrm{PP}}$ & Stored polyphosphates in PAOs & $\mathrm{kg} \mathrm{P} \mathrm{m}^{-3}$ \\
\hline $\mathrm{X}_{\mathrm{PHA}}$ & Storage compound in PAOs & $\mathrm{kg} \mathrm{COD} \mathrm{m} \mathrm{m}^{-3}$ \\
\hline $\mathrm{X}_{\mathrm{AOB}}$ & Ammonia Oxidizing Bacteria & $\mathrm{kg} \mathrm{COD} \mathrm{m}^{-3}$ \\
\hline $\mathrm{X}_{\mathrm{NOB}}$ & Nitrite Oxidizing Bacteria & $\mathrm{kg} \mathrm{COD} \mathrm{m}^{-3}$ \\
\hline $\mathrm{X}_{\mathrm{TSS}}$ & Total suspended solids & $\mathrm{kg} \operatorname{COD~\mathrm {m}^{-3}}$ \\
\hline
\end{tabular}

the literature (Mannina et al., 2011a; Mannina and Di bella, 2012; Di trapani et al., 2010).

The biological sub-models of Model I and Model II are both based on the ASM2d and include the SMP formation/degradation processes (Jiang et al., 2008; Henze et al., 2000). Furthermore, both models consider $\mathrm{CO}_{2}$ as state variable according to the continuity-based model interface as proposed by Vanrolleghem et al. (2005). Despite general similarities, the biological sub-models of Model I and Model II are significantly different (Fig. 1). Model I employs the Hiatt and Grady (2008) approach for describing the processes of the $\mathrm{N}_{2} \mathrm{O}$ production. Consequently, Model I includes a two-step nitrification process (involving $\mathrm{AOB}$ and nitrite oxidizing bacteria, $\mathrm{NOB}$ ) and a four-step denitrification process (Fig. 1). In Model I the $\mathrm{N}_{2} \mathrm{O}$ is modelled as an intermediate product during the heterotrophic denitrification (see, Mannina and Cosenza, 2015). In Model II the $\mathrm{N}_{2} \mathrm{O}$ formation takes both heterotrophic and autotrophic biomass into consideration. Model II describes the $\mathrm{N}_{2} \mathrm{O}$ formation during nitrification combining the two major $\mathrm{AOB}$ formation pathways, according to the approach proposed by Pocquet et al. (2016). Consequently, Model II contains an additional five processes compared with Model I all mediated by $\mathrm{X}_{\mathrm{AOB}}$ : (i) $\mathrm{NH}_{3}$ oxidation to hydroxylamine $\left(\mathrm{NH}_{2} \mathrm{OH}\right)$; (ii) $\mathrm{NH}_{2} \mathrm{OH}$ oxidation to nitric oxide (NO); (iii) $\mathrm{NO}$ oxidation to nitrite $\left(\mathrm{NO}_{2}^{-}\right)$; (iv) $\mathrm{NO}$ reduction to $\mathrm{N}_{2} \mathrm{O}$; (v). $\mathrm{NO}_{2}{ }^{-}$reduction to $\mathrm{N}_{2} \mathrm{O}$. In Model II, the $\mathrm{N}_{2} \mathrm{O}$ formation during the heterotrophic denitrification is described as in Model I.

Model II contains one state variable not considered in Model I, soluble hydroxylamine $-\mathrm{S}_{\mathrm{NH} 2 \mathrm{OH}}$ and another seven model factors $\left(\eta_{\mathrm{AOB}, \mathrm{ND}}, \eta_{\mathrm{AOB}, \mathrm{NN}}, \mathrm{K}_{\mathrm{NH} 2 \mathrm{OH}, \mathrm{AOB}}, \mathrm{K}_{\mathrm{HNO} 2, \mathrm{AOB}}, \mathrm{K}_{\mathrm{NO}, \mathrm{AOB}, \mathrm{HAO}}, \mathrm{K}_{\mathrm{NO}, \mathrm{AOB}, \mathrm{NN}}\right.$ and $\left.\mathrm{K}_{\mathrm{O}, \mathrm{AOB}, \mathrm{ND}}\right)$.

Finally, regarding the stripping of $\mathrm{N}_{2} \mathrm{O}$ and $\mathrm{CO}_{2}$ gas both Model I and II employ an algorithm based on the diffusion coefficients (Mannina et al., 2018).

Model I contains 24 state variables and 109 model factors (stoichiometric, kinetic, fractionation and physical factors) while Model II contains 25 state variables and 116 model factors (Fig. 1).

\subsection{Criteria for comparison}

Model comparison was performed with the following criteria:
- sensitivity analysis, which was assessed with the following indices: (i) similarities in the importance ranking of model factors, (ii) relevance (Rel), which represents the number of important model factors relative to the total number of model factors. The Rel value varies between 0 (no factor is important) and 100\% (all factors are important);

- best fit, which assesses model efficiency ( $\mathrm{E}_{\mathrm{MOD}}$, see Eqs. (3) and (4) and root mean squared error (RMSE) of each ith model output calculated comparing the observed $\left(\mathrm{y}_{\mathrm{obs}, \mathrm{i}}\right)$ and the predicted value $\left(\mathrm{y}_{\text {sim }, \mathrm{i}}\right)$

- model prediction uncertainty, which was assessed by evaluating the pfactor, the r-factor and the Average Relative Interval Length (ARIL) as comparison indices (Yang et al., 2008; Jin et al., 2010): The pfactor is the percentage of observations that lie within the band width - high value (close to 100\%) indicates a low uncertainty of model predictions (Yang et al., 2008). The r-factor is evaluated according to Eq. (1) (Yang et al., 2008).

$\mathrm{r}-$ factor $=\frac{\frac{1}{n} \sum_{i=1}^{n}\left(y_{s i m, 95 \%, i}-y_{\text {sim }, 5 \%, i}\right)}{\sigma_{o b s}}$

where $y_{\text {sim }, 95 \%, i}$ and $y_{\text {sim }, 5 \%, i}$ are the upper and lower boundary value of the ith model output, $\mathrm{n}$ represents the number of observations for each model output and $\sigma_{\mathrm{obs}}$ is the standard deviation of the measured data. A r-factor value close to 1 indicates that the uncertainty band width is very narrow. The ARIL has been evaluated according to Eq. (2).

ARIL $=\frac{1}{n} \sum_{i=1}^{n} \frac{\left(y_{\text {sim }, 95 \%, i}-y_{\text {sim }, 5 \%, i}\right)}{y_{\text {obs }, i}}$

Symbols of Eq. (2) have been already defined. A low ARIL value indicates a low uncertainty of the model predictions.

The combination of a low ARIL value and a high p-factor value suggest a good performance of the model in terms of uncertainty, i.e. a low uncertainty in the model predictions (Dotto et al., 2012; Freni et al., 2009; Freni and Mannina, 2010).

\subsection{Sensitivity analysis, model calibration and uncertainty analysis}

For each model, sensitivity analysis has been performed by adopting a global method. More precisely, the Standardized Regression Coefficients (SRC) method has been applied (Saltelli et al., 2004). This method is based on performing a multivariate regression between model factors and model outputs. On the basis of the value of the slope $\left(\beta_{i}\right)$ of the aforementioned regression it is possible to identify the influence of ith model factor $\left(x_{i}\right)$ on the model output $y$. The value of $\beta_{i}$, which range between -1 and +1 , provides the degree of influence of the ith factor on the $y$ model output. The sign of $\beta_{\mathrm{i}}$ indicates the type of the influence: positive (increasing the $\mathrm{i}^{\text {th }}$ factor means that value $\mathrm{y}$ increases) or negative (the opposite direction of y). For each model, all model factors having the absolute value of $\beta_{i}$ greater than 0.1 have been selected as important. All model factors selected as important were considered during the calibration, all the other model factors were fixed at their value as suggested in literature.

The calibration of both models was performed by adopting the protocol suggested by Mannina et al. (2011b). This protocol is based on a stepwise procedure which groups the calibrated model factors into sub-groups aligned with different aspects of the model which operate relatively independently, i.e. changes of factors within one sub-group result in minimal changes in model outputs related to other sub-groups. For the selected sub-groups of model outputs, a calibration hierarchy is established on the basis of the sum of the $\beta_{i}$ values of the model factors that are important at least for one of the model output of the sub-group (the sub-group having the highest sum of the $\beta_{i}$ values is calibrated as first) Mannina et al. (2011b).

According to the calibration protocol, $N_{c}$ model runs have to be performed by varying only the model factors selected as important 
Table 2

Ranking of all model factors which are important for at least one model output related to the GHG for Model I and Model II. * Rel refers to all model factors.

\begin{tabular}{|c|c|c|c|c|c|c|c|c|c|c|c|c|c|c|c|}
\hline \multirow{3}{*}{$\begin{array}{l}\text { Model output } \\
\operatorname{Rel}^{*}[\%] \\
\text { Factors }\end{array}$} & \multicolumn{5}{|c|}{ Model I } & \multicolumn{10}{|c|}{ Model II } \\
\hline & $\begin{array}{l}\mathrm{S}_{\mathrm{N} 2 \mathrm{O}, 1} \\
3.81\end{array}$ & $\begin{array}{l}\mathrm{S}_{\mathrm{N} 2 \mathrm{O}, 2} \\
4.76\end{array}$ & $\begin{array}{l}\mathrm{S}_{\mathrm{N} 2 \mathrm{O}, 3} \\
5.71\end{array}$ & $\begin{array}{l}\mathrm{S}_{\mathrm{N} 2 \mathrm{O}, 4} \\
8.57\end{array}$ & $\begin{array}{l}\mathrm{S}_{\mathrm{N} 2 \mathrm{O}, 5} \\
8.57\end{array}$ & $\begin{array}{l}\mathrm{S}_{\mathrm{N} 2 \mathrm{O}, 1} \\
6.25\end{array}$ & $\begin{array}{l}\mathrm{S}_{\mathrm{N} 2 \mathrm{O}, 2} \\
8.93\end{array}$ & $\begin{array}{l}\mathrm{S}_{\mathrm{N} 2 \mathrm{O}, 3} \\
8.04\end{array}$ & $\begin{array}{l}\mathrm{S}_{\mathrm{N} 2 \mathrm{O}, 4} \\
15.18\end{array}$ & $\begin{array}{l}\mathrm{S}_{\mathrm{N} 2 \mathrm{O}, 5} \\
15.18\end{array}$ & $\begin{array}{l}\mathrm{S}_{\mathrm{NH} 2 \mathrm{OH}, 1} \\
4.46\end{array}$ & $\begin{array}{l}\mathrm{S}_{\mathrm{NH} 2 \mathrm{OH}, 2} \\
4.46\end{array}$ & $\begin{array}{l}\mathrm{S}_{\mathrm{NH} 2 \mathrm{OH}, 3} \\
8.04\end{array}$ & $\begin{array}{l}\mathrm{S}_{\mathrm{NH} 2 \mathrm{OH}, 4} \\
9.82\end{array}$ & $\begin{array}{l}\mathrm{S}_{\mathrm{NH} 2 \mathrm{OH}, 5} \\
9.82\end{array}$ \\
\hline & \multicolumn{5}{|c|}{ Ranking } & \multicolumn{10}{|c|}{ Ranking } \\
\hline $\mathrm{k}_{\mathrm{H}}$ & 47 & 70 & 24 & 3 & 3 & 52 & 79 & 32 & 7 & 7 & 100 & 89 & 66 & 73 & 73 \\
\hline ko & 50 & 25 & 10 & 2 & 2 & 56 & 34 & 15 & 6 & 6 & 39 & 63 & 25 & 20 & 20 \\
\hline$\mu_{\mathrm{H}}$ & 6 & 5 & 7 & 6 & 6 & 11 & 10 & 11 & 13 & 13 & 84 & 11 & 3 & 3 & 3 \\
\hline $\mathrm{K}_{\mathrm{NH}, \mathrm{H}}$ & 87 & 46 & 42 & 8 & 8 & 93 & 54 & 49 & 16 & 16 & 79 & 85 & 51 & 62 & 62 \\
\hline $\mathrm{q}_{\mathrm{PP}}$ & 17 & 8 & 9 & 24 & 24 & 22 & 14 & 14 & 33 & 33 & 85 & 7 & 6 & 4 & 4 \\
\hline$\mu_{\mathrm{PAO}}$ & 27 & 10 & 30 & 12 & 12 & 33 & 16 & 38 & 20 & 20 & 28 & 6 & 8 & 7 & 7 \\
\hline$\mu_{\text {aut, }, \text { АОВ }}$ & 3 & 3 & 3 & 26 & 26 & 5 & 4 & 7 & 35 & 35 & 6 & 18 & 2 & 2 & 2 \\
\hline $\mathrm{Y}_{\mathrm{H}}$ & 13 & 29 & 6 & 5 & 5 & 17 & 37 & 9 & 12 & 12 & 92 & 108 & 17 & 18 & 18 \\
\hline $\mathrm{Y}_{\mathrm{PAO}}$ & 23 & 11 & 15 & 27 & 27 & 35 & 24 & 20 & 44 & 44 & 57 & 39 & 10 & 9 & 9 \\
\hline $\mathrm{Y}_{\mathrm{PO} 4}$ & 30 & 75 & 79 & 50 & 50 & 29 & 20 & 21 & 36 & 36 & 74 & 12 & 11 & 11 & 11 \\
\hline $\mathrm{f}_{\mathrm{UAP}}$ & 2 & 4 & 2 & 4 & 4 & 4 & 8 & 6 & 9 & 9 & 110 & 79 & 29 & 32 & 32 \\
\hline $\mathrm{F}_{\mathrm{xi}}$ & 28 & 56 & 12 & 9 & 9 & 34 & 64 & 18 & 17 & 17 & 89 & 103 & 55 & 61 & 61 \\
\hline $\mathrm{i}_{\mathrm{N}, \mathrm{xi}}$ & 11 & 14 & 8 & 7 & 7 & 91 & 69 & 78 & 48 & 48 & 51 & 56 & 71 & 64 & 64 \\
\hline $\mathrm{i}_{\mathrm{Nxs}}$ & 64 & 60 & 99 & 23 & 23 & 15 & 23 & 12 & 15 & 15 & 9 & 8 & 23 & 19 & 19 \\
\hline $\mathrm{k}_{\text {,LaT,1 }}$ & 75 & 88 & 5 & 14 & 14 & 99 & 94 & 27 & 41 & 41 & 35 & 59 & 78 & 76 & 76 \\
\hline $\mathrm{k}_{\mathrm{LaT}, 2}$ & 105 & 105 & 46 & 57 & 57 & 81 & 96 & 90 & 56 & 56 & 61 & 74 & 109 & 107 & 107 \\
\hline $\mathrm{k}_{\mathrm{LaT}, 4}$ & 101 & 96 & 97 & 1 & 1 & 108 & 105 & 105 & 5 & 5 & 11 & 29 & 47 & 53 & 53 \\
\hline$\eta_{\mathrm{g} 2}$ & 18 & 57 & 31 & 70 & 70 & 2 & 6 & 3 & 10 & 10 & 21 & 35 & 22 & 24 & 24 \\
\hline$\eta_{\mathrm{g} 3}$ & 99 & 45 & 59 & 65 & 65 & 3 & 7 & 5 & 22 & 22 & 88 & 80 & 65 & 83 & 83 \\
\hline$\eta_{g 4}$ & 4 & 2 & 4 & 20 & 20 & 7 & 2 & 8 & 28 & 28 & 31 & 70 & 20 & 22 & 22 \\
\hline$\eta_{g 5}$ & 1 & 1 & 1 & 16 & 16 & 1 & 1 & 1 & 24 & 24 & 95 & 110 & 77 & 86 & 86 \\
\hline$\eta, \mathrm{AOB}, \mathrm{ND}$ & - & - & - & - & - & 27 & 9 & 2 & 2 & 2 & 5 & 5 & 7 & 8 & 8 \\
\hline $\mathrm{K}_{\mathrm{NH}, \mathrm{AOB}}$ & - & - & - & - & - & 45 & 78 & 106 & 3 & 3 & 104 & 30 & 19 & 30 & 30 \\
\hline $\mathrm{K}_{\mathrm{NH} 2 \mathrm{OH}, \mathrm{AOB}}$ & - & - & - & - & - & 53 & 17 & 17 & 11 & 11 & 3 & 3 & 1 & 1 & 1 \\
\hline $\mathrm{K}_{1, \mathrm{O}, \mathrm{AOB}}$ & - & - & - & - & - & 18 & 12 & 4 & 1 & 1 & 47 & 23 & 9 & 10 & 10 \\
\hline $\mathrm{K}_{\mathrm{O}, \mathrm{AOB}, \mathrm{ND}}$ & - & - & - & - & - & 9 & 3 & 10 & 14 & 14 & 4 & 4 & 14 & 16 & 16 \\
\hline $\mathrm{K}_{\mathrm{O}, \mathrm{AOB} 1}$ & - & - & - & - & - & 10 & 5 & 22 & 4 & 4 & 1 & 1 & 4 & 5 & 5 \\
\hline $\mathrm{K}_{\mathrm{o}, \mathrm{AOB} 2}$ & - & - & - & - & - & 6 & 19 & 29 & 8 & 8 & 2 & 2 & 5 & 6 & 6 \\
\hline
\end{tabular}

In bold important model factors; the two model factors for each model outputs having the highest $\beta_{i}$ value.

within an established variation range (the widest factor variation range found in literature was adopted). For each run the efficiency related to each model output $\left(\mathrm{Y}_{\mathrm{j}}\right)$ and set of model factors $\left(\theta_{\mathrm{i}}\right)$ is evaluated by comparing measured and simulated data (Eq. (3)).

$E_{j}=L\left(\theta_{i} / Y_{j}\right)=\exp \left(\frac{-\sigma_{\mathrm{Mj}-\mathrm{Oj}}^{2}}{\sigma_{\mathrm{Oj}}^{2}}\right)$

Where $\sigma_{\mathrm{Mj}-\mathrm{Oj}}^{2}$ is the sum of squared errors between modelled value $\left(\mathrm{M}_{\mathrm{j}, \mathrm{i}}\right)$ and measured one $\left(\mathrm{O}_{\mathrm{j}, \mathrm{i}}\right)$ of the jth model output; $\sigma_{\mathrm{Oj}}^{2}$ is the sum of the squared errors between $\mathrm{O}_{\mathrm{j}, \mathrm{i}}$ and the average value $\overline{\mathrm{O}}_{\mathrm{j}}$ of the measured $\mathrm{jth}$ model output for the period under analysis.

The calibrated set of model factors is selected on the basis of the maximum value $\left(\mathrm{E}_{\mathrm{MOD}}\right)$ of the weighted sum $\left(\mathrm{E}_{\mathrm{i}}\right)$ of the model efficiency of the $n$ model outputs on the $\theta_{i}$ set of model factors (Eq. (4)).

$\mathrm{E}_{i}=\sum_{\mathrm{j}}^{n} \alpha_{j} L\left(\theta_{i} / Y_{\mathrm{j}}\right)$

Where $\alpha_{j}$ is a constant that represent the weight of the jth model output.

In order to perform uncertainty analysis $N_{u}$ Monte Carlo runs were performed by varying only the important model factors for all the model outputs taken into account. The uncertainty bands related to the $5 \%$ percentile and $95 \%$ percentile of the model likelihood distributions were also evaluated. The results of the Monte Carlo runs were also analyzed on the basis of cumulative distribution function (CDF) for each model output, 5\% and 95\% percentiles.

\subsection{Model application and numerical settings}

Model I and Model II were applied to a pilot plant in a University of Cape Town (UCT) MBR scheme (anaerobic, anoxic, aerobic and MBR reactors in series) treating $20 \mathrm{Lh}^{-1}$ of real wastewater. The plant was equipped by an ultrafiltration hollow fiber membrane module for the solid-liquid separation. Each reactor was equipped with a cover to guarantee the off-gas accumulation and the subsequent gas samples withdrawal.

The pilot plant was operated for 45 days during which the key compounds of the influent, effluent and intermediate plant reactors were analyzed two times per week. The following physical/chemical compounds were measured: total suspended solid (TSS), volatile suspended solids (VSS), total chemical oxygen demand (unfiltered, $\left.\mathrm{COD}_{\mathrm{TOT}}\right)$, supernatant $\mathrm{COD}\left(\mathrm{COD}_{\mathrm{SUP}}\right)$, ammonium nitrogen $\left(\mathrm{NH}_{4}-\mathrm{N}\right)$, nitrite nitrogen $\left(\mathrm{NO}_{2}-\mathrm{N}\right)$, nitrate nitrogen $\left(\mathrm{NO}_{3}-\mathrm{N}\right)$, total nitrogen $(\mathrm{TN})$, phosphate $\left(\mathrm{PO}_{4}-\mathrm{P}\right)$, total phosphorus (TP), biochemical oxygen demand (BOD), $\mathrm{pH}$, dissolved oxygen (DO), temperature. Off-gas and dissolved nitrous oxide $\left(\mathrm{N}_{2} \mathrm{O}\right)$ concentration were measured by using a gas chromatograph (Thermo Scientific ${ }^{\mathrm{TM}}$ TRACE GC) equipped with an electron capture detector. Details on the $\mathrm{N}_{2} \mathrm{O}$ sampling and analysis are found in Mannina et al. (2016b).

For the SRC method application 1200 model runs were performed according to the literature (Vanrolleghem et al., 2015; Cosenza et al., 2013). This number guarantees the stability of the sensitivity measure.

For the model calibration, $N_{c}$ was set equal to 10,000 for each subgroup of model outputs. The broadest factor variation range drawn from literature was adopted. Finally, $N_{u}$ (Monte Carlo runs for the uncertainty analysis) was set equal to 1000 . The value of $N_{u}$ was established by employing independent runs (increasing the number of simulations from 100 to 1000 , at steps of 100) and verifying the stability of the uncertainty results (Bertrand-Krajewski et al., 2002; Dotto et al., 2012).

\section{Results and discussion}

For sake of conciseness, only the results related to the $\mathrm{N}_{2} \mathrm{O}$ model 
outputs (both dissolved and off-gas concentration within each reactor of the UCT-MBR pilot plant) will be presented and discussed.

\subsection{Sensitivity analysis}

Table 2 summarizes the importance ranking of the model factors (both for Model I and Model II) which are important for at least one of the $\mathrm{N}_{2} \mathrm{O}$ model outputs. Furthermore, Table 2 reports for each model output the value of Rel.

A quite high correspondence in terms of set of important model factors occurred between the two models. Almost all model factors found to be important for Model I are also important for Model II (Table 2). In some cases, the results show a perfect correspondence in terms of importance ranking of the most important model factor (number of ranking equal to 1 ). Indeed, for both models $\mathrm{S}_{\mathrm{N} 2 \mathrm{O}, 1}$ (anaerobic reactor), $\mathrm{S}_{\mathrm{N} 2 \mathrm{O}, 2}$ (anoxic reactor) and $\mathrm{S}_{\mathrm{N} 2 \mathrm{O}, 3}$ (aerobic reactor) are mostly influenced by the correction factor for heterotrophic anoxic growth reducing $\mathrm{N}_{2} \mathrm{O}$ to $\mathrm{N}_{2}\left(\eta_{\mathrm{g} 5}\right)$.

A low correspondence in terms of importance ranking occurred for $\mathrm{S}_{\mathrm{N} 2 \mathrm{O}, 4}$ (MBR reactor) and $\mathrm{S}_{\mathrm{N} 2 \mathrm{O}, 5}$ (permeate). For example, for Model I $\mathrm{S}_{\mathrm{N} 2 \mathrm{O}, 4}$ (MBR) and $\mathrm{S}_{\mathrm{N} 2 \mathrm{O}, 5}$ (permeate) are mostly influenced by the overall oxygen transfer coefficient related to MBR tank $\left(\mathrm{K}_{\mathrm{LaT}, 4}\right)$. Conversely, for Model II $\mathrm{S}_{\mathrm{N} 2 \mathrm{O}, 4}$ and $\mathrm{S}_{\mathrm{N} 2 \mathrm{O}, 5}$ are mostly influenced by the $\mathrm{N}_{2} \mathrm{O}$ factor for production inhibition by $\mathrm{O}_{2}\left(\mathrm{~K}_{\mathrm{I}, \mathrm{O} 2, \mathrm{AOB}}\right)$. This discrepancy is mainly related to the fact that in Model II the biological processes occurring inside the aerobic reactor have a predominant effect on the dissolved $\mathrm{N}_{2} \mathrm{O}$ concentration inside the MBR reactor and consequently in the permeate. Conversely, for Model I the stripping processes due to the MBR aeration have a predominant effect on the dissolved $\mathrm{N}_{2} \mathrm{O}$ variation.

The sensitivity analysis demonstrates an influence of the model factors related to the phosphorus transformation processes (e.g., $\mathrm{q}_{\mathrm{PP}}$ and $\mu_{\mathrm{PAO}}$ ) on $\mathrm{S}_{\mathrm{NH} 2 \mathrm{OH}, 3}, \mathrm{~S}_{\mathrm{NH} 2 \mathrm{OH}, 4}$ and $\mathrm{S}_{\mathrm{NH} 2 \mathrm{OH}, 5}$. Such a result has a particular interest since it underlines that even the PAOs activity could have an indirect effect on the $\mathrm{N}_{2} \mathrm{O}$ emission for Model II. The oxygen consumption due to the aerobic PAOs growth could indirectly influence the $\mathrm{AOB} \mathrm{NH}_{2} \mathrm{OH}$ oxidation. Low dissolved oxygen concentration, inside the aerobic reactor, could lead to the incomplete $\mathrm{NH}_{2} \mathrm{OH}$ oxidation with the consequent $\mathrm{N}_{2} \mathrm{O}$ formation as intermediate. This suggests that when phosphorus removal processes are included, the modeler must take consider all the factors related to PAOs activity in order to reduce the $\mathrm{N}_{2} \mathrm{O}$ emissions.

In terms of Rel, it can be observed that despite the greater number of model factors in Model II, the Rel values of all model outputs are higher for Model II than Model I (Table 2). For example, for $\mathrm{S}_{\mathrm{N} 2 \mathrm{O}, 4}$ the Rel value is 8.6 and 15\% for Model I and Model II, respectively (Table 2). This shows that the introduction in Model II of new processes and model factors related to the $\mathrm{N}_{2} \mathrm{O}$ production during nitrification has strongly influenced the model results in terms of GHG emissions from each section of the pilot plant. Indeed, the new model factors introduced in Model II are indicated to be important for almost all the

(a)

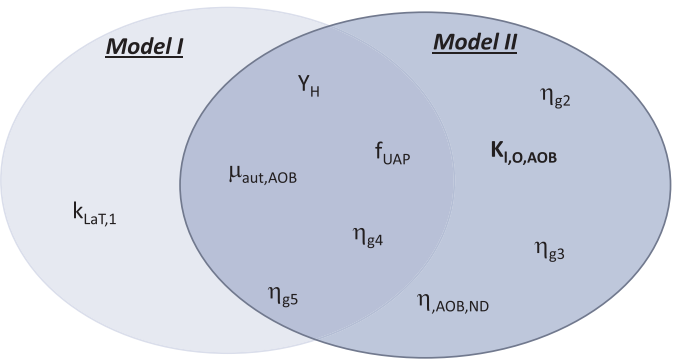

model outputs (Table 2).

Fig. 2 shows the Venn Diagram of the model factors important for the dissolved $\mathrm{N}_{2} \mathrm{O}$ in the aerated reactors $\left(\mathrm{S}_{\mathrm{N} 2 \mathrm{O}, 3}\right.$ and $\left.\mathrm{S}_{\mathrm{N} 2 \mathrm{O}, 4}\right)$. From Fig. 2 it is possible to identify the important model factors for $\mathrm{S}_{\mathrm{N} 2 \mathrm{O}, 3}$ (Fig. 2a) and $\mathrm{S}_{\mathrm{N} 2 \mathrm{O}, 4}$ (Fig. 2b) for each model. Moreover, the overlapping area in Fig. 2 contains the model factors important for Model I and Model II. Fig. 2 shows, especially for the MBR, that a great part of the model factors in common between the two models are important for both $\mathrm{S}_{\mathrm{N} 2 \mathrm{O}, 3}$ (Fig. 2a) and $\mathrm{S}_{\mathrm{N} 2 \mathrm{O}, 4}$ (Fig. 2b). Moreover, almost all the new model factors of Model II are also important (see for example Fig. 2b).

\subsection{Best fit}

Table 3 summarizes the results of the two indices adopted for comparing Model I and Model II in terms of best fit. Specifically, the total model efficiency $\left(\mathrm{E}_{\mathrm{MOD}}\right.$ ) and the average efficiency for both models in terms of $\mathrm{N}_{2} \mathrm{O}$ are reported.

In terms of total model efficiency, a slight improvement of the results was found for Model II.

Indeed, the total model efficiency value for Model II is 0.56 , while for Model I it is 0.55 (Table 3). In general, the values of $E_{M O D}$ (the maximum value is equal to 1 ) are only slightly higher than 0.5 (Table 3). This suggests that the response of both models could be improved. Indeed, both models slightly overestimate the dissolved and off-gas $\mathrm{N}_{2} \mathrm{O}$ for some cases. This result is likely due to the discrete sampling. Continuous sampling would likely improve the results.

Results in terms of single model output show that sometimes a substantial variation in terms of efficiency occurred between Model I and Model II. For example, the efficiency related to the $\mathrm{S}_{\mathrm{N} 2 \mathrm{O}, 2}$ (anoxic reactor) was equal to 0.38 and 0.43 for Model I and Model II, respectively. This is mainly due to the improvement of the $\mathrm{N}_{2} \mathrm{O}$ description in the aerated reactor for Model II, which influences the amount of dissolved $\mathrm{N}_{2} \mathrm{O}$ recycled from the aerated to the anoxic (Section 2) reactors. More precisely, the introduction of the $\mathrm{X}_{\mathrm{AOB}}$ pathways in Model II has led to the increase of the efficiency of $\mathrm{S}_{\mathrm{N} 2 \mathrm{O}, 3}$ (aerobic reactor) from 0.36 to 0.38 in Model I and Model II respectively. Similarly, the efficiency of $\mathrm{S}_{\mathrm{N} 2 \mathrm{O}, 4}(\mathrm{MBR}$ ) increased from 0.30 (Model I) to 0.40 (Model II). Consequently, the efficiency of the off-gas $\mathrm{N}_{2} \mathrm{O}$ model outputs for the MBR increased from 0.35 (Model I) to 0.45 (Model II).

Comparing RMSE, a lower discrepancy between predicted and measured results was found with Model II than with Model I. Indeed, for both models the RMSE value of all model outputs is quite low when compared with the average measured value (Table 3 ). This result suggests that both models provide a quite good description of the measured data. However, the improvement of the results obtained for Model II, as discussed above, is confirmed by the RMSE results. For example, the RSME values related $\mathrm{S}_{\mathrm{N} 2 \mathrm{O}, 2}$ and Off-gas $\mathrm{N} 2 \mathrm{O}, 2_{2}$ and obtained by Model I ( $0.009 \mathrm{mg} \mathrm{L}^{-1}$ and $0.014 \mathrm{mg} \mathrm{L}^{-1}$, respectively) are higher than those of Model II (0.008 $\mathrm{mg} \mathrm{L}^{-1}$ and $0.011 \mathrm{mg} \mathrm{L}^{-1}$, respectively) (Table 3 ). (b)

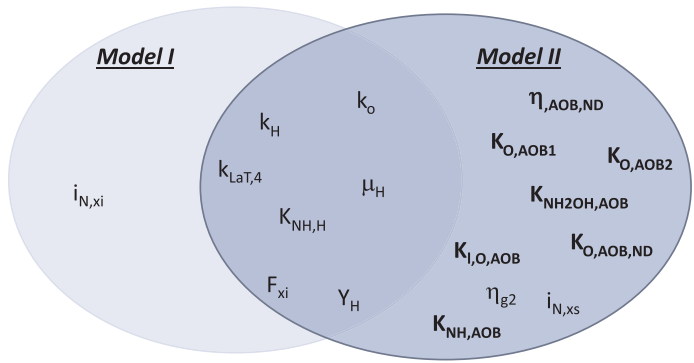

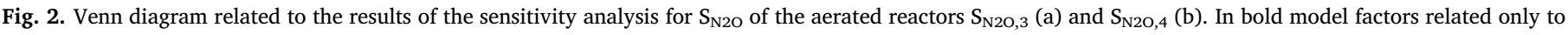
Model II. 
Table 3

Values of the indices adopted for comparing Model I and Model II in terms of best fitting.

\begin{tabular}{|c|c|c|c|c|c|c|c|c|c|c|c|}
\hline Model & Index & $\mathrm{S}_{\mathrm{N} 2 \mathrm{O}, 1}$ & $\mathrm{~S}_{\mathrm{N} 2 \mathrm{O}, 2}$ & $\mathrm{~S}_{\mathrm{N} 2 \mathrm{O}, 3}$ & $\mathrm{~S}_{\mathrm{N} 2 \mathrm{O}, 4}$ & $\mathrm{~S}_{\mathrm{N} 2 \mathrm{O}, 5}$ & Off-gas ${ }_{\mathrm{N} 2 \mathrm{O}, 1}$ & Off-gas $_{\mathrm{N} 2 \mathrm{O}, 2}$ & Off-gas $_{\mathrm{N} 2 \mathrm{O}, 3}$ & Off-gas ${ }_{\mathrm{N} 2 \mathrm{O}, 4}$ & $\mathrm{E}_{\mathrm{MOD}}$ \\
\hline \multirow[t]{2}{*}{ I } & $E_{j}[-]$ & 0.37 & 0.38 & 0.36 & 0.3 & 0.29 & 0.27 & 0.39 & 0.39 & 0.35 & 0.55 \\
\hline & RSME $\left[\mathrm{mg} \mathrm{L}^{-1}\right]$ & 0.013 & 0.009 & 0.009 & 0.01 & 0.013 & 0.021 & 0.014 & 0.013 & 0.014 & \\
\hline \multirow[t]{2}{*}{ II } & $\mathrm{E}_{\mathrm{j}}[-]$ & 0.32 & 0.43 & 0.38 & 0.4 & 0.27 & 0.29 & 0.4 & 0.39 & 0.45 & 0.56 \\
\hline & $\operatorname{RSME}\left[\mathrm{mg} \mathrm{L}^{-1}\right]$ & 0.013 & 0.008 & 0.01 & 0.012 & 0.014 & 0.02 & 0.011 & 0.012 & 0.012 & \\
\hline
\end{tabular}

Table 4

Values of the indices adopted for comparing Model I and Model II in terms of model prediction uncertainty.

\begin{tabular}{|c|c|c|c|c|c|c|c|c|c|c|}
\hline Model & Index & $\mathrm{S}_{\mathrm{N} 2 \mathrm{O}, 1}$ & $\mathrm{~S}_{\mathrm{N} 2 \mathrm{O}, 2}$ & $\mathrm{~S}_{\mathrm{N} 2 \mathrm{O}, 3}$ & $\mathrm{~S}_{\mathrm{N} 2 \mathrm{O}, 4}$ & $\mathrm{~S}_{\mathrm{N} 2 \mathrm{O}, 5}$ & Off-gas ${ }_{\mathrm{N} 2 \mathrm{O}, 1}$ & Off-gas $_{\mathrm{N} 2 \mathrm{O}, 2}$ & Off-gas $_{\mathrm{N} 2 \mathrm{O}, 3}$ & Off-gas $_{\mathrm{N} 2 \mathrm{O}, 4}$ \\
\hline \multirow[t]{3}{*}{ I } & p-factor [\%] & 71 & 86 & 86 & 86 & 71 & 71 & 86 & 43 & 57 \\
\hline & r-factor $[-]$ & 0.001 & 0.732 & 0.470 & 0.000 & 0.098 & 0.254 & 0.981 & 0.321 & 0.144 \\
\hline & ARIL [-] & 0.008 & 2.805 & 0.790 & 0.000 & 0.440 & 2.358 & 4.987 & 3.148 & 2.789 \\
\hline \multirow[t]{3}{*}{ II } & p-factor [\%] & 86 & 86 & 86 & 86 & 86 & 86 & 86 & 86 & 86 \\
\hline & r-factor $[-]$ & 0.388 & 1.110 & 0.114 & 1.007 & 1.233 & 0.879 & 1.457 & 1.249 & 0.751 \\
\hline & ARIL [-] & 1.434 & 1.065 & 0.672 & 1.646 & 1.405 & 1.124 & 1.15 & 1.125 & 1.041 \\
\hline
\end{tabular}

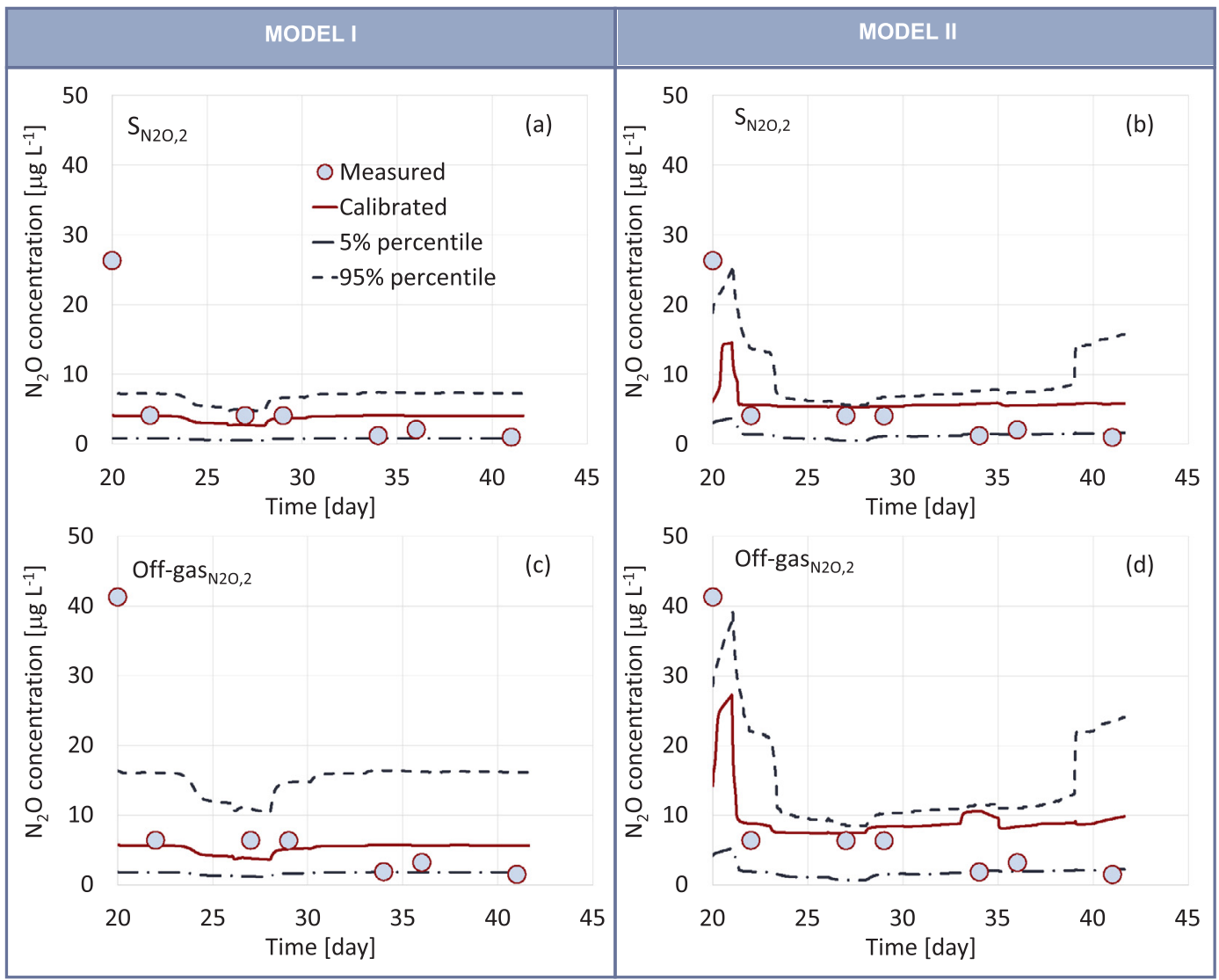

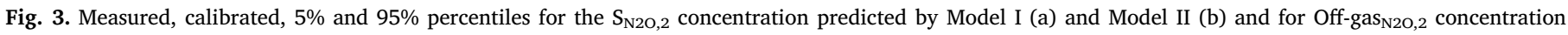
predicted by Model I (c) and Model II (d).

\subsection{Models prediction uncertainty}

Results related to the comparison between the two models in terms of model prediction uncertainty are summarized in Table 4, which summarizes the p-factor, r-factor and ARIL values obtained by Model I and Model II.

In general, the results in Table 4 confirm the global improvement of Model II compared with Model I also in terms of model uncertainty prediction. Indeed, for all the $\mathrm{N}_{2} \mathrm{O}$ model outputs, a lower uncertainty was obtained for Model II when compared to Model I. This is indicated by the higher p-factor values and the ARIL values close to 1 for almost all the outputs of Model II.

In the interests of brevity, only the results related to the $\mathrm{N}_{2} \mathrm{O}$ model outputs (both dissolved and off-gas) of the anoxic and aerobic reactors will be discussed. These two reactors (anoxic and aerobic) were selected because the key processes in them are quite different (directly or indirectly) in the two models.

Fig. 3 shows the measured, calibrated, $5 \%$ and $95 \%$ percentiles for the $\mathrm{S}_{\mathrm{N} 2 \mathrm{O}, 2}$ (anoxic reactor) predicted by Model I and Model II (Fig. 3a and $\mathrm{b}$, respectively) and for Off-gas $\mathrm{N}_{\mathrm{N} 2,2}$ (anoxic reactor) predicted by 


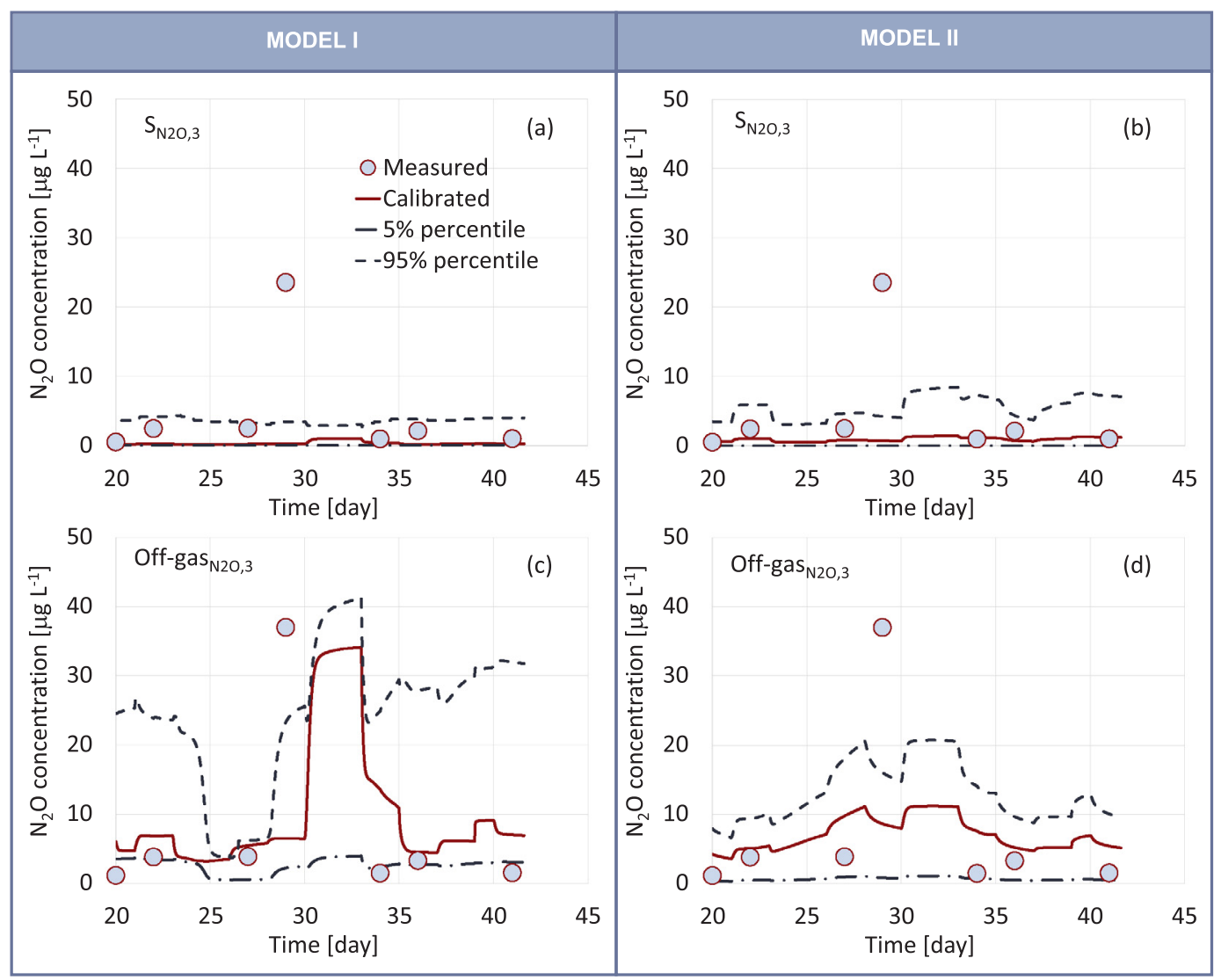

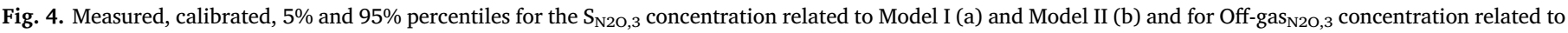
Model I (c) and Model II (d).

Model I and Model II (Fig. 3c and d, respectively).

For $\mathrm{S}_{\mathrm{N} 2 \mathrm{O}, 2}$ an improvement of the model response was obtained for Model II. Indeed, despite the quite high p-factor of $\mathrm{S}_{\mathrm{N} 2 \mathrm{O}, 2}$ and equal for both models (86\%), Fig. $3 \mathrm{a}$ and b show that the calibrated and the $95 \%$ percentile of day 21 for Model II are closer to the measured data. Further, the values of the r-factor and ARIL for $\mathrm{S}_{\mathrm{N} 2 \mathrm{O}, 2}$ (1.11 and 1.065, respectively) of Model II are both very close to 1 which, combined with the high p-factor value, suggest an excellent response of the model in terms of uncertainty (Table 4). Specifically, compared with Model I, for which quite different $r$-factor and ARIL values of $\mathrm{S}_{\mathrm{N} 2 \mathrm{O}, 2}(0.732$ and 2.805 , respectively) were obtained, a lower prediction uncertainty was determined for Model II.

Similar results were also found for Off-gas $\mathrm{N} 2 \mathrm{O}, 2_{2}$ (Fig. 3c,d). Despite similar values of the r-factor (0.981 and 1.457) for Model I and Model II respectively and the p-factor ( $86 \%$ for both models) were obtained for Off-gas $_{\mathrm{N} 2 \mathrm{O}, 2}$, very different ARIL (4.987 and 1.150) values were obtained for Model I and Model II (Table 4). The combination of the low ARIL value and the high p-value for Model II indicates a better per-

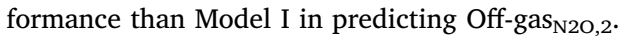

Data related to the aerobic reactor are reported in Fig. 4, which shows the measured, calibrated, $5 \%$ and $95 \%$ percentiles for the $\mathrm{S}_{\mathrm{N} 2 \mathrm{O}, 3}$ (aerobic reactor) predicted by Model I and Model II (Fig. 4a and Fig. 4b, respectively) and for Off-gas $\mathrm{N} 2 \mathrm{O}, 3_{3}$ (aerobic reactor) related to Model I and Model II (Fig. 4c and Fig. 4d, respectively).

For $\mathrm{S}_{\mathrm{N} 2 \mathrm{O}, 3}$ no substantial differences were found in terms of uncertainty of model predictions. Indeed, the p-factor (86\%) value was equal for both models. Further, similar ARIL values for $\mathrm{S}_{\mathrm{N} 2 \mathrm{O}, 3}$ were obtained (namely, 0.790 for Model I and 0.672 for Model II) (Table 4). However, the r-factor of $\mathrm{S}_{\mathrm{N} 2 \mathrm{O}, 3}$ was higher for Model I (0.47) than Model II (0.114) (Table 4). This result suggests that the results of Model I are better than those of Model II for $\mathrm{S}_{\mathrm{N} 2 \mathrm{O}, 3}$ since the $\mathrm{r}$-factor value related to Model I is closer to 1 suggesting an achievement of rather small uncertainty band.

In contrast, for Off-gas $\mathrm{N} 2 \mathrm{O}, 3_{3}$ the results of Fig. $4 \mathrm{~b}$ and c suggest that a net improvement was obtained for Model II. More specifically, for Offgas $_{\mathrm{N} 2 \mathrm{O}, 3}$ a higher p-factor value was obtained with Model II (86\%) than with Model I (43\%) (Table 4). Moreover, the ARIL and r-factor values of Model II (1.125 and 1.249, respectively) are very close to 1 , which suggest a low uncertainty in the model response for Off-gas ${ }_{\mathrm{N} 2 \mathrm{O}, 3}$ (Table 4 and Fig. 4c).

For sake of completeness in Fig. 5 are reported the uncertainty results in terms of $\mathrm{CDF}$ for $\mathrm{S}_{\mathrm{N} 2 \mathrm{O}, 2}$ (a and e for Model I and Model II, respectively), for Off-gas $\mathrm{N} 2 \mathrm{O}, 2_{2}$ (b and f for Model I and Model II, respectively), for $\mathrm{S}_{\mathrm{N} 2 \mathrm{O}, 3}$ (c and $\mathrm{g}$ for Model I and Model II, respectively and for Off-gas ${ }_{\mathrm{N} 2 \mathrm{O}, 3}$ (d and h for Model I and Model II, respectively).

Data reported in Fig. 5 corroborate the improvement of the results obtained with Model II respect to that of Model I. For example, contrary to Model I for Model II the $\mathrm{S}_{\mathrm{N} 2 \mathrm{O}, 2}$ (anoxic reactor) measured data lay all within the $5 \%$ and $95 \%$ percentile CDFs.

No discussion on the measurement error propagation has been here provided because was out of the scope of the study. Further future studies will be performed in view of addressing such a issue (among others, Freni and Mannina, 2010; Freni et al., 2009).

\section{Conclusions}

Two integrated GHGs MBR models have been compared. The following conclusions can be drawn:

1) Most of the model factors introduced into Model II were important for the $\mathrm{N}_{2} \mathrm{O}$ model outputs. Therefore, detailed models (like Model II) provide better results than more simple models (like Model I). 


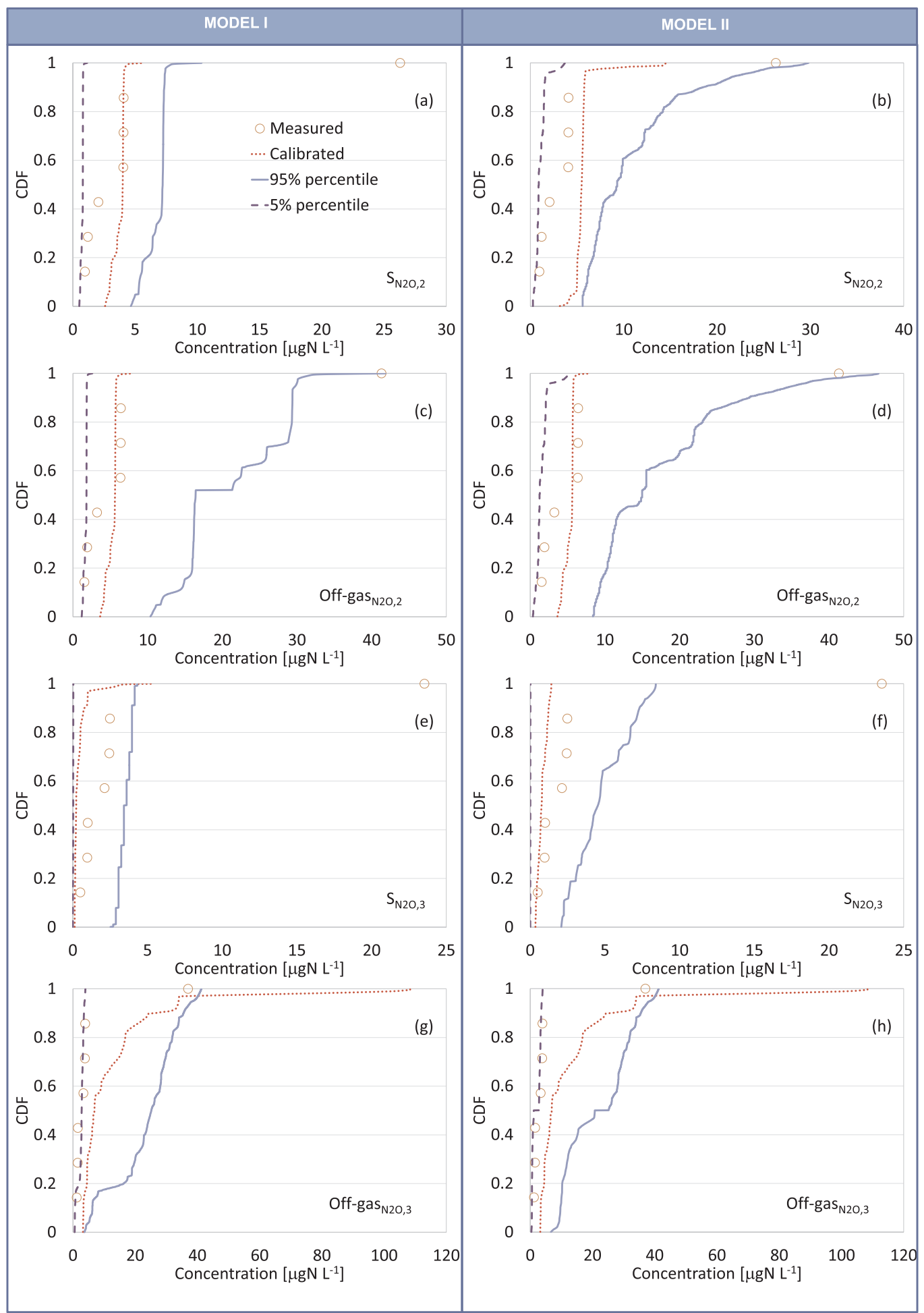

Fig. 5. CDF of measured, calibrated, $5 \%$ and $95 \%$ percentiles for the $\mathrm{S}_{\mathrm{N} 2 \mathrm{O}, 2}$ concentration related to Model I (a) and Model II (b), for Off-gas $\mathrm{N2O,2}$ concentration related to Model I (c) and Model II (d), for the $\mathrm{S}_{\mathrm{N} 2 \mathrm{O}, 3}$ concentration related to Model I (e) and Model II (f), for Off-gas $\mathrm{N} 2 \mathrm{O}, 3_{3}$ concentration related to Model I (g) and Model II (h).

2) The introduction of the AOB pathways in Model II improved predictions in terms of best fit. The efficiency of the off-gas $\mathrm{N}_{2} \mathrm{O}$ model outputs for the MBR increased from 0.35 (Model I) to 0.45 (Model II).

3) The higher complexity of Model II did not negatively influence the uncertainty in model prediction.

\section{Acknowledgments}

This work forms part of a research project supported by grant of the Italian Ministry of Education, University and Research (MIUR) through the Research project of national interest PRIN2012 (D.M. 28 dicembre 2012 n. 957/Ric - Prot. 2012PTZAMC) entitled "Energy consumption and GreenHouse Gas (GHG) emissions in the wastewater treatment plants: a decision support system for planning and management - 
http://ghgfromwwtp.unipa.it" in which the first author is the Principal Investigator. Giorgio Mannina is Fulbright research Fellow at Columbia University, New York, USA. Authors would like also to express their gartitude to prof. Gustaf Olsson for paper proof reading and great input.

\section{Appendix A. Supplementary data}

Supplementary data associated with this article can be found, in the online version, at https://doi.org/10.1016/j.biortech.2018.07.106.

\section{References}

Bertrand-Krajewski, J.L., Barraud, S., Bardin, J.P., 2002. Uncertainties, performance in dicators and decision aid applied to storm water facilities. Urban Water J. 4, 163-179.

Cosenza, A., Mannina, G., Vanrolleghem, P.A., Neumann, M.B., 2013. Global sensitivity analysis in wastewater applications: a comprehensive comparison of different methods. Environ. Modell. Software 49, 40-52.

Dotto, C.B.S., Mannina, G., Kleidorfer, M., Vezzaro, L., Henrichs, M., McCarthy, D.T., Freni, G., Rauch, W., Deletic, A., 2012. Comparison of different uncertainty techniques in urban stormwater quantity and quality modelling. Water Res. 46, 2545-2558.

Di Trapani, D., Mannina, G., Torregrossa, M., Viviani, G., 2010. Giorgio Quantification of kinetic parameters for heterotrophic bacteria via respirometry in a hybrid reactor. Water Scie. Tech. 61 (7), 1757-1766.

Freni, G., Mannina, G., 2010. Uncertainty in water quality modelling: the applicability of variance decomposition approach. J. Hydrol. 394 (3-4), 324-333.

Freni, G., Mannina, G., Viviani, G., 2009. Assessment of data availability influence on integrated urban drainage modelling uncertainty. Environ. Modell. Software 24 (10), 1171-1181.

Henze, M., Gujer, W., Mino, T., Van Loosdrecht, M., 2000. Activated sludge models ASM1, ASM2, ASM2d and ASM3. IWA Task Group on Mathematical Modelling for Design and Operation of Biological Wastewater Treatment. IWA Publishing, London, UK.

Hiatt, W.C., Grady Jr, C.P.L., 2008. An updated process model for carbon oxidation, nitrification, and denitrification. Water Environ. Res. 80, 2145-2156.

IPCC, 2007. Changes in atmospheric constituents and in radiative forcing. In: Solomon, S. (Ed.), Climate Change 2007: The Physical Science Basis. Contribution of Working Group I to the Fourth Assessment Report of the Intergovernmental Panel on Climate Change. Cambridge University Press, Cambridge, pp. 114-143.

Jiang, T., Myngheer, S., De Pauw, D.J.W., Spanjers, H., Nopens, I., Kennedy, M.D., Kennedy, M.D., Amy, G., Vanrolleghem, P.A., 2008. Modelling the production and degradation of soluble microbial products (SMP) in membrane bioreactors (MBR). Water Res. 42 (20), 4955-4964.

Jin, X., Xu, C.Y., Zhang, Q., Singh, V.P., 2010. Parameter and modeling uncertainty simulated by GLUE and a formal Bayesian method for a conceptual hydrological model. J. Hydrol. 383 (3-4), 147-155.

Law, Y., Ni, B.-J., Lant, P., Yuan, Z., 2012. $\mathrm{N}_{2} \mathrm{O}$ production rate of an enriched ammonia- oxidising bacteria culture exponentially correlates to its ammonia oxidation rate. Water Res. 46, 3409-3419.

Li, X., Wang, X., 2006. Modelling of membrane fouling in a submerged membrane bioreactor. J. Membr. Sci. 278, 151-161.

Mannina, G., Capodici, M., Cosenza, A., Di Trapani, D., 2016a. Carbon and nutrient biological removal in a University of Cape Town membrane bioreactor: analysis of a pilot plant operated under two different C/N ratios. Chem. Eng. J. 296, 289-299.

Mannina, G., Cosenza, A., Ekama, G.A., 2018. A comprehensive integrated membrane bioreactor model for greenhouse gas emissions. Chem. Eng. J. 334, 1563-1572.

Mannina, G., Cosenza, A., 2015. Quantifying sensitivity and uncertainty analysis of a new mathematical model for the evaluation of greenhouse gas emissions from membrane bioreactors. J. Membr. Sci. 475, 80-90.

Mannina, G., Di Bella, G., 2012. Comparing two start-up strategies for MBRs: Experimental study and mathematical modelling, chem. Eng. J. 68, 91-103.

Mannina, G., Cosenza, A., Ekama, G.A., 2017. Greenhouse gases from membrane bioreactors: mathematical modelling, sensitivity and uncertainty analysis. Bioresour. Technol. 239, 353-367.

Mannina, G., Cosenza, A., Vanrolleghem, P.A., Viviani, G., 2011a. A practical protocol for calibration of nutrient removal wastewater treatment models. J. Hydroinf. 13 (4), 575-595.

Mannina, G., Di Bella, G., Viviani, G., 2011b. An integrated model for biological and physical process simulation in membrane bioreactors (MBR). J. Membr. Sci. 376 (1-2), 56-69.

Mannina, G., Ekama, G., Caniani, D., Cosenza, A., Esposito, G., Gori, R., Garrido-Baserba, M., Rosso, D., Olsson, G., 2016b. Greenhouse gases from wastewater treatment-a review of modelling tools. Sci. Total Environ. 551-552, 254-270.

Ni, B.-J., Pan, Y., van den Akker, B., Ye, L., Yuan, Z., 2015. Full-scale modeling explaining large spatial variations of nitrous oxide fluxes in a step-feed plug-flow wastewater treatment reactor. Environ. Sci. Technol. 49, 9176-9184.

Pocquet, M., Wu, Z., Queinnec, I., Spérandio, M., 2016. A two pathway model for $\mathrm{N}_{2} \mathrm{O}$ emissions by ammonium oxidizing bacteria supported by the $\mathrm{NO} / \mathrm{N}_{2} \mathrm{O}$ variation. Water Res. 88, 948-959.

Saltelli, A., Tarantola, S., Campolongo, F., Ratto, M., 2004. Sensitivity Analysis in Practice. A Guide to Assessing Scientific Models, Probability and Statistics Series. John Wiley \& Sons Publishers, Chichester, England.

Spérandio, M., Pocquet, M., Guo, L., Ni, B.-J., Vanrolleghem, P.A., Yuan, Z., 2016. Evaluation of different nitrous oxide production models with four continuous longterm wastewater treatment process data series. Bioprocess Biosyst. Eng. 39, 493-510.

Sweetapple, C., Fu, G., Butler, D., 2013. Identifying key sources of uncertainty in the modelling of greenhouse gas emissions from wastewater treatment. Water Res. 47, 4652-4665.

Vanrolleghem, P.A., Mannina, G., Cosenza, A., Neumann, M.B., 2015. Global sensitivity analysis for urban water quality modelling: terminology, convergence and comparison of different methods. J. Hydrol. 522, 339-352.

Vanrolleghem, P.A., Rosen, C., Zaher, U., Copp, J., Benedetti, L., Ayesa, E., Jeppsson, U., 2005. Continuity-based interfacing of models for wastewater systems described by Petersen matrices. Water Sci. Technol. 52, 493-500.

Yang, J., Reichert, P., Abbaspour, K.C., Xia, J., Yang, H., 2008. Comparing uncertainty analysis techniques for a SWAT application to the Chaohe Basin in China. J. Hydrol. 358, 1-23. 